\title{
Invasive Johnsongrass, a threat to native grasslands and agriculture
}

\author{
Peter Klein ${ }^{1}(\mathbb{D}) \cdot$ Charles Michael Smith ${ }^{1}$
}

Received: 6 March 2020 / Accepted: 9 October 2020 / Published online: 22 October 2020

(C) The Author(s) 2020

\begin{abstract}
Among the weedy plant species, Johnsongrass (Sorghum halepense) is one of the most destructive. Johnsongrass has invaded new habitats beyond its native Eurasian origin by outcompeting native flora and cultivated crops. The Johnsongrass habitat is expanding continuously due to clonal and self-pollinating reproduction strategy, accelerated growth and the progressing climate change. As a result, Johnsongrass has reduced native plant diversity in grasslands and inflicted economic damage to agriculture on every continent. Johnsongrass is a growing threat to crop production, as it serves as a refuge for a variety of agricultural pests and plant viral diseases. Over the past decades, herbicides extensively applied to control Johnsongrass have boosted selection pressure, resulting in the independent evolution of herbicide-resistant ecotypes across multiple locations. The apparent threat to native flora and agriculture caused by the invasive Johnsongrass is a subject to a long and ongoing research. This review provides a historical and research overview on Johnsongrass expansion, its current as well future impact particularly on North American and European grasslands and agriculture.
\end{abstract}

Keywords Agricultural damage · Climate change · Habitat expansion · Herbicide resistance · Invasive species · Johnsongrass · Noxious weed $\cdot$ Perennial grass $\cdot$ Pest and plant virus host $\cdot$ Sorghum halepense $\cdot$ Threat to native flora

\section{Introduction}

Among the worldwide relevant weeds, Johnsongrass is one of the top 10 noxious global mild-latitude weeds. Johnsongrass was introduced to the U.S. separately, in South Carolina and Arizona (Sezen et al. 2016). The earliest introduction occurred around 1830 through contaminated cotton seeds from Egypt successfully invading agricultural pastures and natural plains in South Carolina (McWhorter 1971). Johnsongrass is classifies as weed in over 53 countries occurring in 30 different crops (Masood et al. 2017; Ryder et al. 2018). Dense Johnsongrass populations in crop fields have been shown to impact the yield quantity causing substantial damage to agriculture.

The narrow-leaved Johnsongrass seedlings exhibit a significant similarity to cultivated annual grain and can be misidentified as sorghum or maize plants. However, adult plants develop a distinct morphological phenotype reaching up to $2.5 \mathrm{~m}$ height and stems between 0.5 and $2.0 \mathrm{~cm}$ in

Peter Klein

pklein@ksu.edu

1 Department of Entomology, Kansas State University, 124 W Waters Hall, Manhattan, KS 66506, USA diameter. The veined leaves with a prominent mid-vein expand up to $60 \mathrm{~cm}$ in length and $3.3 \mathrm{~cm}$ in width. In flowering, the panicle is erected and pyramidal gaining a size of up to $50 \mathrm{~cm}$. Below ground Johnsongrass develops an extensive subterranean rhizome network that can resemble up to $70 \%$ of the entire plant dry weight (Paterson et al. 2020).

Johnsongrass naturally hybridizes with various Sorghum species resulting in new perennial and rhizomatous hybrids able to persist harsh environment and establish themselves in new habitats. For example, up to $72 \%$ of S. bicolor and S. halepense $\mathrm{F}_{2}$ hybrid offsprings develop rhizomes and able to withstand subzero winter temperatures with a survival rate of up to $71 \%$. Studies on S. halepense crossings with various other Sorghum species result also in rhizomatous progenies (Yim and Bayer 1997). For instance, Sorghum almum develops rhizomes and between $1050-43110$ seeds per plant. Its set of $2 n=40$ chromosomes resembled during hybridization between Johnsongrass and cultivated Sorghum. Alongside of Johnsongrass $S$. almum is also considered as weed spanning across five continents (North America, South America, Europe, Africa and Australia). However, in comparison to Johnsongrass S. almum rhizomes survive in warm climates but did not withstand the winter in colder regions resulting in lower invasiveness if compared to the noxious parent (Eberlein et al. 1988). Meanwhile, Johnsongrass established itself permanently in grasslands and 
agricultural fields not only in tropical and moderate climate regions but also demonstrates resilience in colder parts of the world such as Canada. Already in 1983 Johnsongrass was reported in Southern Ontario (Warwick and Black 1983). In that habitat Johnsongrass proves its toughness as one of the most noxious weeds by tolerating heat waves exceeding $32{ }^{\circ} \mathrm{C}$ and regular temperature plunges to $-26^{\circ} \mathrm{C}$ aboveground at the coldest time of the year (Smoyer et al. 2000; Coiner et al. 2018). This northward expansion of Johnsongrass might be associated with the progressing global climate change. The potential global average temperature rise up to $4.5^{\circ} \mathrm{C}$ accompanied with doubled preindustrial atmospheric $\mathrm{CO}_{2}$ levels by the end of the next century could expand the range of plant species between 500 and $1000 \mathrm{~km}$ to the north. For instance, those dramatic climate changes would disturb the diversity and distribution of the vegetation in North America creating favorable condition for Johnsongrass expansion throughout the continent (Overpeck et al. 1991).

\section{Sorghum halepense origin and evolution}

Currently, 25 taxonomically distinct species are recognized in the genus Sorghum which are dispersed throughout 5 subgenera: Eusorghum, Chaetosorghum, Heterosorghum, Parasorghum and Stiposorghum with chromosome counts of $2 \mathrm{n}=10,20$, 30, 40 (Garber 1950; Lazarides et al. 1991). The Sorghum subclass Eusorghum harbors the species Sorghum propinquum, Sorghum halepense and Sorghum bicolor. The later resembles the only cultivated Sorghum varieties. Most of the Sorghum species are wild or weedy with varying inter and intraspecific compatibility ranging between 0 and $100 \%$ (Venkateswaran et al. 2019). However, Sorghum halepense ancestors Sorghum bicolor and Sorghum propinquum have been shown to have itself a common ancestor and an estimated divergence of around 2 million years (Guo et al. 2019). In contrast to Sorghum propinquum a substantial archaeological evidence suggests the cultivation and domestication of Sorghum bicolor in the central Sahara area $7500-7100 \mathrm{BC}$ and its wide spread as an important crop in Asia and India between 4000-3500 BC (Winchell et al. 2018). The tetraploid Sorghum halepense ( $2 \mathrm{n}=$ 40 ) emerged less than 2 million years ago during a natural hybridization and chromosome duplication between diploid $(2 \mathrm{n}=$ 20) Sorghum bicolor, a drought resistant crop native to tropical Africa, and rhizomatous southeast Asian Sorghum propinquum gaining the ability for vegetative reproduction by rhizomes (Warwick and Black 1983; Kong et al. 2013; Cox et al. 2018; Paterson et al. 2020). S. halepense origin has been established by protein sequence polymorphism studies resulting in $99.4 \% \mathrm{nu}-$ cleotide match compared to $S$. bicolor, S. propinquum and outgroup $S$. timorense. Further, the remaining $0.6 \%$ of nucleotides match S. bicolor to $10.9 \%$ but deviate from S. propinquum and $6.6 \%$ vice versa (Paterson et al. 2020).

\section{Johnsongrass as invasive plant species}

One of the remarkable prosperity factors of Johnsongrass is selfpollination (Dweikat 2005). It blooms 46 days after emergence and produces up to 80000 seed per plant in a single season which remain viable for up to 10 years in the soil (McWhorter 1961; Ryder et al. 2018). Johnsongrass has a broad seed depth germination rate ranging from $64 \%$ at $1 \mathrm{~cm}$ to $30 \%$ at $20 \mathrm{~cm}$ depth. Up to $6 \%$ of its seeds are able to germinate from depths as low as $25 \mathrm{~cm}$ (Toth and Lehoczky 2006). The ability of Johnsongrass to produce modified subterranean stems, the rhizomes, enabling it to reproduce vegetatively by generating adventitious roots and new shoots as the main factor for its invasiveness similar to other rhizomatous weed species such as Calystegia hederacea, Solanum eleaegnifolium and Cirsium (Xiqing et al. 2016; Kariyat and Chavana 2018; Nunes and Kotanen 2018; Gu et al. 2019). The rhizome biomass allocation in Johnsongrass is with $31-37 \%$ significantly higher than in all sexual reproductive structures that ranges between $9-11 \%$ similar to other rhizomatous grass species, suggesting the clonal reproduction strategy as a sink for limited resources (Wilson and Thompson 1989; Benech Arnold et al. 1992). Rhizomes are essential organs in storing carbohydrates and minerals. Further, secondary metabolites produces in $S$. halepense root system have been shown to have a negative effect on popular medical plants grown in Iran such as Ocimum basilicum, Nigella sativa, Cuminumcyminum, Foeniculum vulgare, Plantago ovata and Plantago psyllium (Asgharipour and Armin 2010). Similar effects were observed in wheat. Wheat seed germination ration dropped by $30 \%$ exposed to $S$. halepense root extract. Further, it was demonstrated that $S$. halepense root tissue extracts have a negative impact on wheat seedling, radicle, and coleoptile development reducing the plant fresh weight significantly (Hamid et al. 2012). The rhizome multifunctionality combined with their allelopathic effects on competitor plants might contribute to the enhanced competitiveness and invasiveness of Johnsongrass (Anderson et al. 1960; Jang et al. 2009). A single plant can produce a rhizome network more than $60 \mathrm{~m}$ in in length in 152 days (McWhorter 1961). During early development, Johnsongrass plants gain up to 4-fold more biomass than North American prairie grasses Panicum virgatum L. (switchgrass), Schizachyrium scoparium (Michx) Nash (little bluestem) and Andropogon gerardii Vitman (big bluestem), due to increased leaf area, higher atmospheric carbon uptake and photosynthetic nitrogen-use efficiency (Reichmann et al. 2016). Greenhouse simulated seedling competition experiments between Johnsongrass and these same $\mathrm{C}_{4}$ plant species resulted in a dramatic $95 \%$ biomass loss in the native species if grown along with Johnsongrass, which suffered a moderate $11 \%$ loss of non-root biomass (Schwinning et al. 2017). Transcriptome assembly analysis and annotation studies of Johnsongrass resulted in 6447 potential protein coding sequences. Its bioinformatic coding sequence analysis between Thinopyrum intermedium, a 
rhizomatous and perennial grass, and the seasonal nonrhizomatous $S$. bicolor resulted in the identification of 98 candidate sequences involved in Johnsongrass rhizome development. Among these, the most expressed protein families belong to ZIM (zinc finger inflorescence meristem) family, DNA binding proteins, transcription factors and the Armadillo (ARM)repeat superfamily which have been shown to play crucial roles in hormone signaling, development by exhibiting a differential expression pattern during environmental stress responses (Ryder et al. 2018). Similarly, the analysis of Johnsongrass ancestor $S$. propinquum promoter regions shows an enrichment of cisregulatory elements involved in abscisic acid (ABA) and gibberellic acid (GA) responses, suggesting a cross-talk between those hormones in rhizomes. Both phytohormones are key regulators in rhizome development. In particular, promoter regions of differentially expressed genes in rhizome tip tissue are enriched with gibberellin regulated cis-elements such as pyrimidine box TATCAA and CAREs box (Jang et al. 2006). Additional genes enriched in rhizome tips are linked to hormone signaling pathways, sugar response and transport, cell cycle, cell division and development as well as splicing factors that enable biotic and abiotic stress tolerance.

\section{Johnsongrass impacts on agriculture}

The density of Johnsongrass plants is a critical factor that affects surrounding vegetation, and floral biomass loss accumulates drastically due to Johnsongrass density. A single Johnsongrass plant in an $8 \mathrm{~m}$ plant row decreased cotton yield by $7.12 \%$ and when densities increased to 32 plants/ $8 \mathrm{~m}$ plant row cotton yield dropped by $30 \%$ (Uludag et al. 2007). Similar results were observed in in the U. S. in Texas, where a single Johnsongrass plant/15 m cotton plant row reduced yield by 34\$/hectare (Wood et al. 2002). Further studies demonstrated a significant cotton yield increase when treating Johnsongrass infested fields with herbicide fluazifop, where treating plots 3 weeks post-Johnsongrass emergence produced the same cotton quantity as weed-free lots. However, plot treatments delayed by 3, 5, 9 and 22 weeks reduced cotton yields by 20-, 60-, 80and 90\%, respectively (Keeley and Thullen 1989).

Soybean (Glycine max) is an important legume crop and was domesticated 3000 to 5000 years ago in Asia with a spread out of Asia 250 years ago (Lee et al. 2011; Liu et al. 2017). Due to its high protein and oil content and low carbohydrate content, it is widely used for animal feed and human consumption (Sedivy et al. 2017; Rizzo and Baroni 2018). Weeds such as Johnsongrass can drastically impact soybean production. Johnsongrass density of 32 culms / 10 m reduces soybean yield by 13 - to $38 \%$ if it is allowed to compete uncontrolled for 6 weeks. The reduction increased up to $69 \%$ at a 7-week competition and reached $88 \%$ at full-season competition (Williams and Hayes 1984). In addition, field plot experiments with soybean varieties heavily infested with Johnsongrass demonstrated yield reductions of between 23and $42 \%$ over a 3 -year period (McWhorter and Hartwig 1972). Similar effects were observed in corn (Zea mays), where uncontrolled 4-week competition between corn and Johnsongrass grown from rhizomes resulted in $10-14 \%$ less corn silage. A season-long competition between corn and Johnsongrass led to more than $80 \%$ corn seed loss compared to weed-free corn plots (Mitskas et al. 2003). In addition to crop yield losses from Johnsongrass competition, producers controlling Johnsongrass with herbicides incur expenses of between $\$ 12$ to $\$ 20$ per acre for herbicides and their application, establishing Johnsongrass as a serious threat to constantly increasing human demands for food (Paterson et al. 1995).

\section{New habitat colonization and the role of climate change}

In U.S. Great Plains as defined in 2000 are stretching throughout 475 counties and 11 states along the southern latitude of the 32nd degree spanning from the Midwest to Rocky mountains (east to west) and from northern Canada to central Texas (north to south) (Sylvester et al. 2013). The natural grassland ecosystem is shaped by the north-south temperature and the east-west precipitation gradient with annual rainfall between 1200 and $300 \mathrm{~mm}$ and temperatures from below $0{ }^{\circ} \mathrm{C}$ and above $20^{\circ} \mathrm{C}$ (Gutmann et al. 2005). These ecoregions appear to be most suitable for invasive plant species including Johnsongrass. A large number of collected Johnsongrass populations in those regions suggests a permanent establishment, high climatic compatibility and suitable biotic and abiotic conditions. In computer models the Synthetic Ecoclimatic Index (EI) estimating the growth and stress factors was generated for Johnsongrass on the global scale. Predicted climate niche for Johnsongrass with suitable EI values $>20$ stretches throughout all but Antarctic continents reaching habitats as north as Canada and Sweden, if water supply is available. According to computer models the wide niche range, Johnsongrass is able to colonize $62 \%$ of North American and $80 \%$ of U.S. ecoregions. In the continental US Johnsongrass showed a climate match between 50\%-90\% in all 20 designated ecoregions excelling particularly in plains and prairies (Barney and DiTomaso 2011). Broad Johnsongrass dispersion predictions are confirmed in field studies where 939 out of 2077 visited sites resulted in the verified occurrence of Johnsongrass (Ohadi et al. 2018). Common North Americas $\mathrm{C}_{4}$ prairie species such the big bluestem (Andropogon gerardii), switchgrass (Panicum virgatum) and the little bluestem (Schiachyrium scoparium) are forced to compete with the perennial Johnsongrass belonging to the same functional group over territory and resources. The early grow schedule of invasive plant species is a key factor to gain the competition advantage. Faster seed germination, seedling growth and higher leafe area 
have been shown as characteristic traits for invasiveness. In comparison to three native prairie species Johnsongrass seeds germinate faster and gain fourfold size advantage within first 17 days post germination compared to its competitors (Reichmann et al. 2016). A 13 - 30 fold higher Johnsongrass biomass production compared to three native species 50 days after seeding illustrates the potential threat to native flora (Schwinning et al. 2017). Under natural conditions prairie land is reigned by a high grass cover until woody species begin to dominate and drive it back proportionally. Undisturbed Oklahoma prairie plots showed the grass cover at $90 \%$ for a decade. The most dominant species such as Schizaehyrium scoparium, Andropogon gerardii, Panicum virgatum, and Sorghastrum nutans were pushed back to $38 \%$ during the rise of woody plants after 9 years, reaching maximal woody cover percentage of $58 \%$ after 32 years. A single plow however eliminates woody species and reduces the prairie grass cover opening the gate for pioneer invaders. In those areas the grass cover stagnates at $60 \%-70 \%$ for almost 2 decades dominated by native perennial Leptoloma cognatum and invasive Johnsongrass. Similarly, annually plowed prairie was promptly populated by various weed species including Johnsongrass (Collins and Adams 1983). Johnsongrass has proven itself similarly successful in US Texas. The Fort Worth Prairie is populated by geographically characteristic native grass species such as Schizachyrium, Bouteloua curtipendula, Sporobolus compositus, Bouteloua hirsuta, Sorghastrum nutans, and Andropogon gerardii. However, over the past four decades a field study measured an overrun by Johnsongrass from the north, area previously used for agricultural purposes. The observed mean advancement of Johnsongrass in native prairie is $0.45 \mathrm{~m}$ per annum diminishing the native flora diversity by transforming the native grassland into transitional and subsequently into invaded prairie. The aerial cover Johnsongrass for each invasion stage reaches from $0 \%$ in native to $27 \%$ in transitional and $77 \%$ in invaded prairie pushing back the presence of native species by $47 \%$ while expanding the rhizomatous growth and altering the soil biochemistry during the invasion process (Rout and Chrzanowski 2009; Rout et al. 2013). The displacement rate of native grass species may vary depending on the geographic. For instance, various Panicum virgatum biotypes exhibit significant differences between age of first flowering, plant height, biomass, shots, and seed count per plant changing factors local flora modulation (Palik et al. 2016). Efforts to reestablish native flora on abandoned farmland have been proven to be difficult. A blunt native grass seed sowing effort does not alter the overall biomass of invasive grasses, including Johnsongrass. However, if combined with a physical removal the Johnsongrass biomass decreased by $63 \%$ while increasing the overall biomass by nearly $25 \%$ after 2 years of the experiment. Worth mentioning is that sowed grass species tend to form concentrated patches instead of a homogeneous distribution indicating a labor and time consuming recovery process (Tognetti and Chaneton 2012). Delaying the grassland transition to later vegetation succession stages by grazing and aboveground burning slows down subsequently also the weed propagation, including Johnsongrass (Davidson 1993).

Furthermore, the globally progressing climate change has a positive effect on Johnsongrass propagation. Rising temperatures and change in precipitation could potentially unlock currently unreachable habitats. Long term studies affecting the weed propagation in Oklahoma U.S. under warming and precipitation conditions resulted in changed soil temperature as well the soil water content during experimental settings. On those plots the dominant $\mathrm{C}_{3}$ biomass decreased and $\mathrm{C}_{4}$ biomass increased over eight years constantly. Within the first three years a switch from $73 \% \mathrm{C}_{3}$ group biomass to $78 \% \mathrm{C}_{4}$ biomass was observed. The annual weedy grass and forbs community including species such as Bromus japonicus and Ambrosia trifida was transformed mostly to perennial bunchgrass Tridens flavus and Sorghum halepense (Shi et al. 2018). Similarly, increased territorial advancements of Johnsongrass due to the increasing global temperature are reported from Austria, Germany and other warm regions of Europe since the beginning of the 1990s. Depending on economy priorities and population growth in Germany and Austria in the next decades a conservatively forecasted average temperature increase between $0.9{ }^{\circ} \mathrm{C}-2.9{ }^{\circ} \mathrm{C}$ due to global climate change is expected, if compared to the average reference temperature between 1961 and 1990 (Kleinbauer et al. 2010). The increase of temperature supports the current findings in Johnsongrass expansion trajectory. Between 1965 and 1999 in total 13 grids $\left(33 \mathrm{~km}^{2}\right)$ clustered in the south-eastern crop fields and three in the northeastern part of Austria were colonized by Johnsongrass. Meanwhile, in years between 2000 and 2016 Johnsongrass populations were recorded in 42 grids concentrating in the south but with a clear expansion into northern crop fields (Follak et al. 2017). In 2010 the Johnsongrass records in fields increased to $>100$ and $>190$ outside of fields (Follak and Essl 2012). As of 2017 Johnsongrass is threatening to expand exponentially throughout 168000 ha agricultural area (Follak et al. 2017).

Further, the climate change associated high atmospheric $\mathrm{CO}_{2}$ concentration stimulates the plant growth and the photosynthesis while simultaneously inhibiting the plant transpiration. Therefore, significant increase of air $\mathrm{CO}_{2}$ content could have the potential to alter entire ecosystems (Tian et al. 2019). Those changes might level the field for invasive plant species, especially such as the broad niche compatible Johnsongrass.

\section{Emerging herbicide resistance in Johnsongrass}

Before the use of specialized herbicides for Johnsongrass, the species was controlled by repeated deep tilling and hoeing (Poienaru et al. 2005). Later, pre-emergent application of broad 
range herbicides such as Guardian MAX, Merlin and Stromp 330 EC showed it to be highly effective against Johnsongrass infestations (Toth and Lehoczky 2007). Presently, susceptible Johnsongrass plants are controlled from 88 - to $97 \%$ with quizalofop, glyphosate, imazethapyr plus imazapyr, nicosulfuron, and primisulfuron herbicides and 56\% with glufosinate herbicide 3 weeks after treatment (Johnson et al. 2003). Over the past decades, however, glyphosate (N-(phosphonomethyl) glycine) has evolved as the most preferred herbicide with more than 8.6 billion $\mathrm{kg}$ sold since 1974 (Benbrook 2016). Glyphosate controls systematically perennial weeds such as Johnsongrass (Baylis 2000). However, intensive world-wide glyphosate application has created glyphosate resistance in 35 known weed species, including Johnsongrass (Heap and Duke 2018). In Argentina, Johnsongrass has developed independent multiple types of resistance towards glyphosate requiring higher dosages for effective control (Vila-Aiub et al. 2007; Fernandez et al. 2013). Computer models accounting for complete plant life cycle including rhizomes and seeds were used to simulate decades of Johnsongrass resistance allele frequencies in populations exposed to glyphosate.

Recurrent nicosulfuron application to seedling- and rhizomeemerged Johnsongrass has also created resistant Johnsongrass biotypes with 33- to 46 times higher herbicide resistance than susceptible control plants (Hernández et al. 2015). Johnsongrass poses an exclusive threat to cultivated $S$. bicolor due to its close ancestry. In Texas and Nebraska, up to $32 \%$ of unique S. bicolor alleles were identified in Johnsongrass populations adjacent to long-term Sorghum production sites. The obtained evidence strongly suggests that engineered genes and herbicide resistance can potentially be transferred into Johnsongrass and widely disseminated (Morrell et al. 2005).

\section{Johnsongrass, a pathogen source for cultivated plants}

Over $25 \%$ of all existing flora is estimated to serve as host for more than 4000 phloem-feeding Aphidae (aphid) families (Dedryver et al. 2010; Jaouannet et al. 2014). Roughly 100 species of aphids are economically relevant species (Emden and Harrington 2007) which incur global agricultural crop losses of billions of dollars annually (Emden and Harrington 2007). Despite feeding-based biomass reductions due to significant chlorophyll and carotenoid removal from damaged plants (Riedell and Kieckhefer 1995; Ni and Quisenberry 2006; Ni et al. 2013), aphids also have the potential to vector at least 275 plant viruses. The potyviruses Maize Dwarf Mosaic Virus (MDMV), Sugarcane Mosaic Virus (SCMV), Johnsongrass Mosaic Virus (JGMV), and Sorghum Mosaic Virus (SrMV) are commonly found in corn, Johnsongrass and Sorghum, cause corn and sorghum yield losses of up to $70 \%$, mostly by causing leaf necrosis and photosynthesis shutdown (Garrido 1993;
Wamaitha et al. 2018; Seifers et al. 2000). The severity potential of MDMV cross-contamination between Johnsongrass and crop plants was demonstrated in samples collected from Ohio (U. S.) which indicated that 20 of 33 Johnsongrass plants were infected with MDMV compared to 43 of 56 maize plants (Stewart et al. 2014). Virus identification studies on corn and Johnsongrass in cornfields suggest MDMV and SCMV viruses transfer from Johnsongrass to corn (Mohammadi et al. 2006), however, virus transmission strategies among and between plant species are highly diverse. Around 50\% of all plant viruses are transmitted by aphids in a non-persistent mechanism (Hooks and Fereres 2006). To identify suitable host plants, aphids use their stylets to sample phloem sap. During this process, the stylets contact the plant cell content and included virons which if acquired, are transmitted by probing to healthy plants, and initiating the infection process in the host plant (James and Falk 2006).

\section{Conclusions}

With the progressing global climate change the available habitat for the noxious weed Johnsongrass continues to expand. Due to predominantly clonal reproduction and speedy development Johnsongrass has already managed to colonize wide prairie stretches and infested farmland almost throughout the entire globe. Native grassland plant species are often subject to displacement if confronted with the broad niche invasive Johnsongrass. The destructive effect on agriculture could be not overstated. Significant crop yield losses are attributed to Johnsongrass itself competing for resources. Additionally, Johnsongrass serves an alternative host for a number of agricultural pest and vector-based plant diseases that are naturally transferred to cultivated plants. The control of Johnsongrass has proven to be a challenging endeavor. Physical plant destruction by plowing results in fragmented rhizomes and subsequently more rapidly growing clones and extensive eradication efforts by herbicides led to the evolution of herbicide resistant ecotypes hindering the management of this invasive species in the future.

Funding This study was funded by National Institute of Food and Agriculture - USDA (grant number 2015-68004-23492).

\section{Compliance with ethical standards}

Conflict of interest The corresponding author, Peter Klein, has received research grants from NIFA-USDA. The coauthor Michael C. Smith has received research grants from NIFA-USDA.

Open Access This article is licensed under a Creative Commons Attribution 4.0 International License, which permits use, sharing, adaptation, distribution and reproduction in any medium or format, as long as you give appropriate credit to the original author(s) and the source, provide a link to the Creative Commons licence, and indicate if changes were made. The images or other third party material in this article are included in the article's Creative Commons licence, unless indicated otherwise in a 
credit line to the material. If material is not included in the article's Creative Commons licence and your intended use is not permitted by statutory regulation or exceeds the permitted use, you will need to obtain permission directly from the copyright holder. To view a copy of this licence, visit http://creativecommons.org/licenses/by/4.0/.

\section{References}

Anderson LE, Appleby AP, Weseloh JW (1960) Characteristics of Johnsongrass Rhizomes. Weeds 8:402-406

Asgharipour MR, Armin M (2010) Inhibitory effects of sorghum halepens root and leaf extracts on germination and early seedling growth of widely used medicinal plants . Adv Environ Biol 4:316-324

Barney JN, DiTomaso JM (2011) Global climate niche estimates for bioenergy crops and invasive species of agronomic origin: potential problems and opportunities. PLoS One 6:e17222. https://doi.org/10. 1371/journal.pone. 0017222

Baylis (2000) Why glyphosate is a global herbicide: strengths, weaknesses and prospects. Pest Manag Sci 56:299-308

Benbrook CM (2016) Trends in glyphosate herbicide use in the United States and globally. Environ Sci Eur 28:28:23. https://doi.org/10. 1186/s12302-016-0070-0

Benech Arnold RL, Fenner M, Edwards PJ (1992) Mineral allocation to reproduction in Sorhum bicolor and Sorghum halepense in relation to parental nutrient supply. Oecologia 92:138-144. https://doi.org/ 10.1007/BF00317274

Coiner HA, Hayhoe K, Ziska LH, Van Dorn J, Sage RF (2018) Tolerance of subzero winter cold in kudzu (Pueraria montana var. lobata). Oecologia 187:839-849. https://doi.org/10.1007/s00442-018-4157-8

Collins SL, Adams DE (1983) Succession in grasslands: Thirty-two years of change in a central Oklahoma tallgrass prairie. Vegetatio 51:181-190

Cox S, Nabukalu P, Paterson AH, Kong W, Nakasagga S (2018) Development of Perennial Grain Sorghum. Sustainability 10:172-300

Davidson DW (1993) The effects of herbivory and granivory on terrestrial plant succession. Oikos 68:23-35

Dedryver CA, Ralec AL, Fabre F (2010) The conflicting relationships between aphids and men: a review of aphid damage and control strategies. C R Biol 333:539-553. https://doi.org/10.1016/j.crvi. 2010.03.009

Dweikat I (2005) A diploid, interspecific, fertile hybrid from cultivated sorghum, sorghum bicolor, and the common Johnsongrass weed sorghum halepense. Mol Breed 16:7

Eberlein CV, Miller TL, Lurvey EL (1988) Seasonal emergence and growth of Sorghum almum. Weed Tech 2:275-281

Emden HFV, Harrington R (2007) Aphids as crop pests. CABI, Wallingford, 30

Fernandez L et al (2013) Population genetics structure of glyphosateresistant Johnsongrass (Sorghum halepense L. Pers) does not support a single origin of the resistance. Ecol Evol 3:3388-3400. https:// doi.org/10.1002/ece3.671

Follak S, Essl F (2012) Spread dynamics and agricultural impact of Sorghum halepense, an emerging invasive species in Central Europe. Weed Res 53:53-60. https://doi.org/10.1111/j.1365-3180. 2012.00952.x

Follak S, Schleicher C, Schwarz M, Essl F (2017) Major emerging alien plants in Austrian crop fields. Weed Res 57:406-416. https://doi. org/10.1111/wre. 12272

Garber ED (1950) Cytotaxonomic studies in the genus Sorghum. Univ Calif Publ Bot 23:283-362
Garrido M (1993) Occurrence of Johnsongrass mosaic virus on sorghum in Venezuela. Plant Dis 77:4

Gu X, Cen Y, Guo L, Li C, Yuan H, Xu Z, Jiang G (2019) Responses of weed community, soil nutrients, and microbes to different weed management practices in a fallow field in Northern China. PeerJ 7: e7650. https://doi.org/10.7717/peerj.7650

Gutmann MP, Parton WJ, Cunfer G, Burke IC (2005) Population and Environment in the U.S. Great Plains. Population, Land Use, pp 84-105

Guo H, Jiao Y, Tan X, Wang X, Huang X, Jin H, Paterson AH (2019) Gene duplication and genetic innovation in cereal genomes. Genome Res 29:261-269. https://doi.org/10.1101/gr.237511.118

Hamid N, Ansari TZ, Abolfazl T (2012) Effect of weed allelopathic of sorghum (Sorghum halepense) on germination and seedling growth of wheat Alvand cultivar. Ann Biol Res 3:1283-1293

Heap I, Duke SO (2018) Overview of glyphosate-resistant weeds worldwide. Pest Manag Sci 74:1040-1049. https://doi.org/10.1002/ps.4760

Hernández M, León R, Fischer A, Gebauer M, Galdames R (2015) Target-site resistance to Nicosulfuron in Johnsongrass (Sorghum halepense) from Chilean Corn Fields. Weed Sci 63:631-640

Hooks CR, Fereres A (2006) Protecting crops from non-persistently aphid-transmitted viruses: a review on the use of barrier plants as a management tool. Virus Res 120:1-16. https://doi.org/10.1016/j. virusres.2006.02.006

James CKN, Falk BW (2006) Virus-vector interactions mediating nonpersistent and semipersistent transmission of plant viruses. Annu Rev Phytopathol 44:183-212. https://doi.org/10.1146/annurev. phyto.44.070505.143325

Jang CS, Kamps TL, Skinner DN, Schulze SR, Vencill WK, Paterson AH (2006) Functional classification, genomic organization, putatively cis-acting regulatory elements, and relationship to quantitative trait loci, of sorghum genes with rhizome-enriched expression. Plant Physiol 142:1148-1159. https://doi.org/10.1104/pp.106.082891

Jang CS, Kamps TL, Tang H, Bowers JE, Lemke C, Paterson AH (2009) Evolutionary fate of rhizome-specific genes in a non-rhizomatous Sorghum genotype. Heredity 102:266-273. https://doi.org/10.1038/ hdy.2008.119

Jaouannet M, Rodriguez PA, Thorpe P, Lenoir CJ, MacLeod R, Escudero-Martinez C, Bos JI (2014) Plant immunity in plant-aphid interactions. Front Plant Sci 5:663-673. https://doi.org/10.3389/ fpls.2014.00663

Johnson W, Li J, Wait J (2003) Johnsongrass control, total nonstructural carbohydrates in rhizomes, and regrowth after application of herbicides used in herbicide-resistant corn (Zea mays). Weed Technol 17:36-41

Kariyat RR, Chavana J (2018) Field data on plant growth and insect damage on the noxious weed Solanum eleaegnifolium in an unexplored native range. Data Brief 19:2348-2351. https://doi.org/10. 1016/j.dib.2018.07.022

Keeley EP, Thullen RJ (1989) Growth and interaction of Johnsongrass (Sorghum Halepense) with cotton (Gossypium Hirsutum). Weed Sci 37:339-344

Kleinbauer I, Dullinger S, Klingenstein F, May R, Nehring S, Essl F (2010) Ausbreitungspotenzial ausgewählter neophytischer Gefäßpflanzen unter Klimawandel in Deutschland und Österreich Umweltbundesamt. https://www.bfn.de/fileadmin/BfN/service/ Dokumente/skripten/skript275.pdf. Accessed 24 June 2020

Kong W et al (2013) Genetic analysis of recombinant inbred lines for Sorghum bicolor x Sorghum propinquum. G3(3):101-108. https:// doi.org/10.1534/g3.112.004499

Lazarides M, Hacker JB, Andrew MH (1991) Taxonomy, cytology and ecology of indigenous Australian sorghums (Sorghum Moench: Andropogoneae: Poaceae). Aust Syst Bot 4:591-635 
Lee GA, Crawford GW, Liu L, Sasaki Y, Chen X (2011) Archaeological soybean (Glycine max) in East Asia: does size matter? PLoS One 6: e26720. https://doi.org/10.1371/journal.pone.0026720

Liu $\mathrm{Z}$ et al (2017) Comparison of genetic diversity between Chinese and American soybean (Glycine max (L.)) accessions revealed by highdensity SNPs. Front Plant Sci 8:2014. https://doi.org/10.3389/fpls. 2017.02014

Masood PA et al (2017) Eco-biology, impact, and management of Sorghum halepense (L.) Pers. Biol Invasions. https://doi.org/10. 1007/s10530-017-1410-8

McWhorter CG (1961) Morphology and development of Johnsongrass plants from seeds and rhizomes. Weeds 9:558-562

McWhorter CG (1971) Introduction and spread of Johnsongrass in the United States. Weed Sci 19:496-501

McWhorter C, Hartwig E (1972) Competition of Johnsongrass and Cocklebur with six soybean varieties. Weed Sci 20:56-59

Mitskas M, Tsolis C, Eleftherohorinos I, Damalas C (2003) Interference between corn and johnsongrass (Sorghum halepense) from seed or rhizomes. Weed Sci 5:540-545

Mohammadi MR, Koohi-Habibi M, Mosahebi G, Hajieghrari B (2006) Identification of prevalent potyvirus on maize and johnsongrass in corn fields of Tehran province of Iran and a study on some of its properties. Commun Agric Appl Biol Sci 71:1311-1319

Morrell PL, Williams-Coplin TD, Lattu AL, Bowers JE, Chandler JM, Paterson AH (2005) Crop-to-weed introgression has impacted allelic composition of johnsongrass populations with and without recent exposure to cultivated sorghum. Mol Ecol 14:2143-2154. https:// doi.org/10.1111/j.1365-294X.2005.02579.x

Ni X et al (2013) Dynamic change in photosynthetic pigments and chlorophyll degradationelicited by cereal aphid feeding. Entomol Exp Appl 105:43-53

Ni X, Quisenberry SS (2006) Diuraphis noxia and Rhopalosiphum padi (Hemiptera: Aphididae) interactions and their injury on resistant and susceptible cereal seedlings. J Econ Entomol 99:551-558. https:// doi.org/10.1603/0022-0493-99.2.551

Nunes KA, Kotanen PM (2018) Comparative impacts of aboveground and belowground enemies on an invasive thistle. Ecol Evol 8:1430 1440. https://doi.org/10.1002/ece3.3751

Ohadi S, Littlejohn M, Mesgaran M, Rooney W, Bagavathiannan M (2018) Surveying the spatial distribution of feral sorghum (Sorghum bicolor L.) and its sympatry with johnsongrass (S. halepense) in South Texas. PLoS One 13:e0195511. https:// doi.org/10.1371/journal.pone.0195511

Overpeck JT, Bartlein PJ, Webb T (1991) Potential magnitude of future vegetation change in eastern north america: comparisons with the past. Science 254:692-705. https://doi.org/10.1126/science.254.5032.692

Palik DJ, Snow AA, Stottlemyer AL, Miriti MN, Heaton EA (2016) Relative performance of non-local cultivars and local, wild populations of switchgrass (Panicum virgatum) in competition experiments. PLoS One 11:e0154444. https://doi.org/10.1371/journal.pone.0154444

Paterson AH et al (2020) The evolution of an invasive plant, Sorghum halepense L. ('Johnsongrass'). Front Genet 11:317. https://doi.org/ $10.3389 /$ fgene. 2020.00317

Paterson AH, Schertz KF, Lin YR, Liu SC, Chang YL (1995) The weediness of wild plants: molecular analysis of genes influencing dispersal and persistence of johnsongrass, Sorghum halepense (L.) Pers. Proc Natl Acad Sci U S A 92:6127-6131. https://doi.org/10.1073/pnas.92.13.6127

Poienaru S, Sarpe N, Sarpe I (2005) The chemical control of Shorgum halepense (Johnson grass) in soybean culture in the Danube meadow. Commun Agric Appl Biol Sci 70:459-463
Reichmann LG, Schwinning S, Polley HW, Fay PA (2016) Traits of an invasive grass conferring an early growth advantage over native grasses. J Plant Ecol 9:9

Riedell WE, Kieckhefer RW (1995) Feeding damage effects of three aphid species on wheat root growth. J Plant Nutr 18:10

Rizzo G, Baroni L (2018) Soy, soy foods and their role in vegetarian diets nutrients 10. https://doi.org/10.3390/nu10010043

Rout ME, Chrzanowski T (2009) The invasive Sorghum halepense harbors endophytic $\mathrm{N}_{2}$-fixing bacteria and alters soil biogeochemistry. Plant Soil 315:163-172

Rout ME, Chrzanowski TH, Smith WK, Gough L (2013) Ecological impacts of the invasive grass Sorghum halepense on native tallgrass prairie. Biol Invasions 15:327-339

Ryder N et al (2018) Transcriptome assembly and annotation of johnsongrass (Sorghum halepense) rhizomes identify candidate rhizome-specific genes. Plant Direct 2:e00065. https://doi.org/10.1002/pld3.65

Schwinning S, Meckel H, Reichmann LG, Polley HW, Fay PA (2017) Accelerated development in Johnsongrass seedlings (Sorghum halepense) suppresses the growth of native grasses through sizeasymmetric competition. PLoS One 12:e0176042. https://doi.org/ 10.1371/journal.pone. 0176042

Sedivy EJ, Wu F, Hanzawa Y (2017) Soybean domestication: the origin, genetic architecture and molecular bases. New Phytol 214:539-553. https://doi.org/10.1111/nph.14418

Seifers DL et al (2000) Characterization of a novel potyvirus isolated from maize in Israel. Phytopathology 90:505-513. https://doi.org/ 10.1094/PHYTO.2000.90.5.505

Sezen UU et al (2016) Multi-phase US spread and habitat switching of a post-columbian invasive, Sorghum halepense. PLoS One 11: e0164584. https://doi.org/10.1371/journal.pone.0164584

Shi $\mathrm{Z}$ et al (2018) Successional change in species composition alters climate sensitivity of grassland productivity. Glob Chang Biol 24: 4993-5003. https://doi.org/10.1111/gcb.14333

Smoyer KE, Rainham DG, Hewko JN (2000) Heat-stress-related mortality in five cities in Southern Ontario: 1980-1996. Int J Biometeorol 44:190-197. https://doi.org/10.1007/s004840000070

Stewart LR et al (2014) Viruses in maize and Johnsongrass in southern Ohio. Phytopathology 104:1360-1369. https://doi.org/10.1094/ PHYTO-08-13-0221-R

Sylvester KM, Brown DG, Deane GD, Kornak RN (2013) Land transitions in the American plains: Multilevel modeling of drivers of grassland conversion (1950 to 2000). Agric Ecosyst Environ 168: 7-15. https://doi.org/10.1016/j.agee.2013.01.014

Tian D et al (2019) Global changes alter plant multi-element stoichiometric coupling. New Phytol 221:807-817. https://doi.org/10.1111/nph.15428

Tognetti PM, Chaneton EJ (2012) Invasive exotic grasses and seed arrival limit native species establishment in an old-field grassland succession. Biol Invasions :2531-2544. https://doi.org/10.1007/s10530-012-0249-2

Toth V, Lehoczky E (2006) Investigations on the germination depth of Johnson grass (Sorghum halepense [L.] pers). Commun Agric Appl Biol Sci 71:803-808

Toth V, Lehoczky E (2007) The analysis of the effect of different herbicides on Johnson-grass in maize Commun. Agric Appl Biol Sci 72: 279-282

Uludag A, Gozcu D, Rusen M, Guvercin RS, Demir A (2007) The effect of johnsongrass (Sorghum halepense (L.) Pers.) densities on cotton yield. Pak J Biol Sci 10:523-525

Venkateswaran K, Elangovan M, Sivaraj N (2019) Origin, Domestication and Diffusion of Sorghum bicolor. Breeding Sorghum for Diverse End Uses, pp 15-31 
Vila-Aiub M, Balbi M, Gundel P, Ghersa C, Powles S (2007) Evolution of Glyphosate-Resistant Johnsongrass (Sorghum halepense) in Glyphosate-Resistant Soybean. Weed Sci 55:6

Wamaitha MJ et al (2018) Metagenomic analysis of viruses associated with maize lethal necrosis in Kenya. Virol J 15:90. https://doi.org/ 10.1186/s12985-018-0999-2

Warwick S, Black L (1983) The Biology of Canadian Weeds. Can J Plant Sci 63:997-1014

Williams CS, Hayes RM (1984) Johnsongrass (Sorghum Halepense) competition in soybeans (Glycine Max). Weed Sci 32:3

Wilson AM, Thompson KJ (1989) A comparative study of reproductive allocation in 40 British grasses. Funct Ecol 3:297-302. https://doi. org/10.2307/2389369

Winchell F et al (2018) On the origins and dissemination of domesticated Sorghum and pearl millet across Africa and into India: a View from the Butana Group of the Far Eastern Sahel. Afr Archaeol Rev 35: 483-505. https://doi.org/10.1007/s10437-018-9314-2
Wood ML, Murray DS, Banks JC, Verhalen LM, Westerman RB, Anderson KB (2002) Johnsongrass (Sorghum halepense) density effects on cotton (Gossypium hirsutum) harvest and economic value. Weed Technol 16:495-501

Xiqing M, Qian X, MW A, Bingru H (2016) Hormone regulation of rhizome development in tall fescue (Festuca arundinacea) associated with proteomic changes controlling respiratory and amino acid metabolism. Ann Bot 118:481-494

Yim KO, Bayer DE (1997) Rhizome expression in a selected cross in the Sorghum genus. Euphytica 94:6. https://doi.org/10.1023/A: 1002974000365

Publisher's note Springer Nature remains neutral with regard to jurisdictional claims in published maps and institutional affiliations. 